\title{
TOLERANSI PASCAKONFLIK ANTARAGAMA DI TOBELO
}

\author{
H. Hans Panjaitan \\ Reformed Center for Religion and Society
}

\begin{abstract}
This article on the "Tolerance of Interreligious Conflict in Tobelo" will measure the level of religious tolerance in Tobelo District to see the current state of religious tolerance in Tobelo. This study was conducted in the form of a survey to high school students in Tobelo District. Tobelo student's opinion can be a gauge to see the level of religious tolerance in Tobelo. This research found that the level of interreligious tolerance in Tobelo is high, however based on the survey, the integration among community groups that have been involved in the conflict must be improved to foster mutual trust among different religious groups. Therefore, this research suggests that local governments should continue to foster the soul and tolerance spirit among religious followers by, for example, building diverse communities of religions, especially within the scope of education.
\end{abstract}

KEYWORDS: tolerance, conflict, religion, tolerance education, Tobelo

ABSTRAK: Artikel "Toleransi Pascakonflik Antaragama di Tobelo" ini akan mengukur tingkat toleransi beragama di Kabupaten Tobelo untuk melihat kondisi terkini terkait tingkat toleransi beragama di Tobelo. Penelitian ini dilakukan dalam bentuk survei terhadap siswa sekolah menengah atas di Kabupaten Tobelo. Pendapat siswa Tobelo dapat menjadi alat ukur untuk melihat tingkat toleransi beragama di Tobelo. Temuan penelitian ini adalah: tingkat toleransi antaragama di Tobelo tinggi, namun berdasarkan data survei integrasi antar-kelompok masyarakat yang pernah terlibat konflik itu masih harus ditingkatkan untuk menumbuhkan rasa saling percaya antar-kelompok masyarakat yang berbeda agama. Karena itu saran penelitian ini adalah pemerintah 
daerah sepatutnya terus menumbuhkan jiwa dan semangat toleransi di antara pemeluk agama dengan misalnya, membangun komunitaskomunitas beragam agama, khususnya dalam lingkup pendidikan.

KATA-KATA KUNCI: toleransi, konflik, agama, pendidikan toleransi, Tobelo

\section{Pendahuluan}

Toleransi beragama di Tobelo, Kabupaten Halmahera Utara (Halut), Provinsi Maluku Utara, pernah terkoyak, seiring dengan terjadinya konflik paling berdarah beberapa waktu silam. Penduduk Tobelo terdiri dari berbagai macam keyakinan/agama. Sebelum pecah kerusuhan yang membawa-bawa nama agama, semua orang hidup rukun dan damai, penuh semangat gotong-royong dan toleransi. Namun setelah era reformasi bergulir, keadaan yang kondusif itu tiba-tiba terusik. Pada 27 Desember 1999 timbul pertikaian di antara warga yang berbeda keyakinan. Warga satu kampung yang selama ini hidup berdampingan dengan damai dan penuh toleransi, tiba-tiba beringas dan saling membunuh. Pemicunya hanya isu yang tak jelas asal mulanya. Dibutuhkan waktu yang lama dan kesabaran yang sangat tinggi untuk membuat suasana kembali aman dan damai di kawasan ini. Konflik Tobelo telah reda, namun usaha untuk mencegah konflik selanjutnya perlu diusahakan. Penelitian ini penting bukan hanya mengetahui kondisi toleransi Tobelo saat ini, tetapi menjadi dasar untuk terus meningkatkan toleransi beragama di Tobelo yang merupakan faktor penting untuk menghindari kemungkinan konflik yang sama berlanjut.

\section{Sekilas tentang Tobelo}

Tobelo merupakan salah satu kecamatan yang ada di Kabupaten Halmahera Utara (Halut), Provinsi Maluku Utara. Berdasarkan Undang Undang Nomor 53 Tahun 2008, Kabupaten Halmahera Utara mengalami pemekaran menjadi dua kabupaten yaitu Kabupaten Halmahera Utara dan Kabupaten Pulau Morotai. Sejak pemekaran, jumlah desa di Halmahera Utara menjadi 196 desa yang terbagi dalam 17 kecamatan, 
dari jumlah semula 260 desa dan 22 kecamatan.

Halmahera Utara merupakan wilayah kepulauan yang dikelilingi oleh lautan dan sebagian besar wilayahnya atau 78 persen merupakan lautan. Sebelah utara berbatasan dengan Samudera Pasifik dan Kabupaten Pulau Morotai, sebelah timur berbatasan dengan Laut Halmahera dan Kabupaten Halmahera Timur, sebelah selatan dan barat berbatasan dengan Kabupaten Halmahera Barat.

Kabupaten Halmahera Utara terdiri atas 17 kecamatan, masingmasing: 1) Malifut, 2) Kao, 3) Kao Utara, 4) Kao Barat, 5) Kao Teluk, 6) Tobelo, 7) Tobelo Tengah, 8) Tobelo Utara, 9) Tobelo Selatan, 10) Tobelo Timur, 11) Tobelo Barat, 12) Galela, 13) Galela Utara, 14) Galela Selatan, 15) Galela Barat, 16) Loloda Utara, dan 17) Loloda Kepulauan.

Berdasarkan hasil Proyeksi Penduduk 2015, penduduk Halmahera Utara berjumlah 180.100 jiwa, yang terdiri dari 92.099 jiwa laki-laki dan 88.001 jiwa perempuan. Tobelo merupakan kecamatan dengan penduduk terbanyak yaitu 33.325 jiwa, kemudian disusul Kecamatan Tobelo Selatan dan Tobelo Tengah dengan jumlah penduduk masing-masing 14.482 jiwa dan 14.114 jiwa, sementara itu kecamatan dengan penduduk paling sedikit adalah Kao Teluk, dengan jumlah penduduk 3.946 jiwa.

Halmahera Utara memiliki masyarakat yang beragam atau multiagama dan multietnis. Sehingga sarana dan prasarana yang menunjang kehidupan masyarakat pun beragam. Salah satu fasilitas yang penting ketersediaannya adalah tempat peribadatan. Berdasarkan data pada tahun 2016, di Kabupaten Halmahera Utara terdapat 142 masjid, 440 gereja. $^{1}$

Luas wilayah Kecamatan Tobelo tercatat $50,88 \mathrm{Km}^{2}$ yang terbagi menjadi 10 (sepuluh) Desa dengan batas-batas wilayah sebelah utara berbatasan dengan Kecamatan Tobelo Utara, sebelah timur berbatasan

\footnotetext{
1 Statistik Daerah Kabupaten Halmahera Utara Tahun 2017, Nomor Katalog: 1101002.8205, BPS Halmahera Utara.
} 
dengan Kabupaten Pulau Morotai, sebelah selatan berbatasan dengan Kecamatan Tobelo Tengah, sedangkan sebelah barat berbatasan dengan Kabupaten Halmahera Barat. Letak ibu kota Kecamatan Tobelo berada di Desa Gamsungi. ${ }^{2}$

Penduduk Kecamatan Tobelo tahun 2016 sebesar 31.548 jiwa. Jumlah penduduk terbesar berada di Desa Gamsungi yakni sebesar 7.882 jiwa, disusul Desa Gosoma dengan jumlah penduduk 6.071 jiwa, sedangkan jumlah penduduk terkecil yakni Desa Tagalaya dengan jumlah 452 jiwa. Kepadatan penduduk per $\mathrm{km}^{2}$. Adapun tempat ibadah yang ada se-Kecamatan Tobelo adalah masjid 16 buah, surau/langgar 2, gereja Protestan 36, dan gereja Katolik 1.

Tabel:

Jumlah Penduduk Kecamatan Tobelo Berdasarkan Agama Tahun $2016^{3}$

\begin{tabular}{|c|c|c|c|c|c|c|}
\hline $\begin{array}{c}\text { DESA/ } \\
\text { KELURAHAN }\end{array}$ & ISLAM & KRISTEN & KATOLIK & HINDU & BUDDHA & JUMLAH \\
\hline Gamsungi & 3,446 & 4,296 & 131 & 1 & 8 & 7,882 \\
\hline Gura & 895 & 3,466 & 87 & 9 & 0 & 4,457 \\
\hline Wari & 454 & 2,011 & 74 & 0 & 0 & 2,539 \\
\hline Kakara & 53 & 707 & 1 & 0 & 0 & 761 \\
\hline Kumo & 0 & 685 & 1 & 0 & 0 & 686 \\
\hline Gosoma & 2,533 & 4,105 & 69 & 0 & 0 & 6,707 \\
\hline Rawajawa & 4,378 & 324 & 7 & 0 & 0 & 4,710 \\
\hline MKCM & 130 & 1,727 & 657 & 0 & 0 & 2,514 \\
\hline Tagalaya & 0 & 448 & 4 & 0 & 0 & 452 \\
\hline
\end{tabular}

2 Kecamatan Tobelo dalam Angka 2017, Nomor Katalog: 1102001.8205040, Badan Pusat Statistik Kabupaten Halmahera Utara, diakses 24 April 2018, pukul 14.18.

3 Kecamatan Tobelo dalam Angka 2017. 
Wari Ino 5 1,279 7 0 1 1,292

Sumber: Dinas Kependudukan dan Catatan Sipil Kabupaten Halmahera Utara

\section{Konflik Tobelo}

Sebagaimana wilayah Indonesia pada umumnya, Tobelo sejak dahulu kala tenang, aman dan damai. Walaupun penduduknya terdiri dari berbagai macam keyakinan/agama, namun semua orang hidup rukun dan damai, penuh semangat toleransi. Namun setelah era reformasi bergulir, keadaan yang kondusif itu tiba-tiba terusik. Pada 27 Desember 1999 timbul pertikaian di antara warga yang berbeda keyakinan. Warga satu kampung yang selama ini hidup berdampingan dengan damai dan penuh toleransi, tiba-tiba saja saling baku pukul, saling bunuh. Pemicunya hanya isu yang tak jelas asal-mulanya. SMS (short message service) yang beredar tentang adanya seorang warga dibunuh oleh warga yang beragama berbeda. Dan karena konflik semakin panas dan meluas, banyak warga yang mengungsi. Untuk mengetahui sekilas bagaimana situasi dan kondisi masyarakat sebelum konflik meletus, berikut ini cuplikan pengalaman hidup nyata dari seorang warga yang dimuat di kompas.com:

Sebelas tahun silam Fardi masih duduk di bangku SMP. Ia sangat menikmati kehidupan remajanya yang ceria di Tobelo, sebuah wilayah di Pulau Halmahera sebelah utara. Dunianya waktu itu hanyalah belajar di sekolah dan bermain dengan gembira bersama teman-teman sebaya. Hidupnya berubah total ketika kerusuhan melanda tempat tinggalnya. Orang- orang yang dulu dia kenal saling berhubungan dengan baik satu sama lain kini bermusuhan. Mereka saling menyerang. Dibantu pihak dari luar Tobelo, mereka membakar rumah-rumah warga dan tanpa ragu membunuh orang lain. Alam pikiran Fardi waktu itu tidak bisa mencerna mengapa warga Tobelo menjadi begitu kejam dan tidak mengenal lagi persaudaraan. Fardi tahu ada warga Tobelo yang beragama Kristen dan ada pula yang beragama Islam. Namun, sebelumnya tidak pernah kedua 
kelompok itu saling menyerang. Sebaliknya, mereka hidup berdampingan dengan penuh damai, saling mengunjungi pada hari-hari besar kedua agama tersebut. Fardi remaja tidak bisa paham mengapa perbedaan agama tiba-tiba bisa memotivasi orang untuk bertindak bengis terhadap sesamanya. ${ }^{4}$

Peristiwa ini sangat mengejutkan mengingat selama ini kehidupan warga masyarakat di kawasan ini sangat baik. Walaupun warga berbeda agama dan keyakinan, namun semua orang menjunjung tinggi nilai-nilai toleransi dan kekerabatan. Tapi, hanya gara-gara masalah sepele dan isu yang tidak jelas kebenarannya, suasana damai dan harmonis yang diwariskan nenek moyang sejak ratusan tahun silam, sirna dalam sekejap. Masyarakat yang tadinya selalu ramah-tamah terhadap sesama, tanpa memandang latar belakang agama dan ras, menjadi saling curiga dan marah. Dibutuhkan waktu yang lama dan kesabaran untuk membuat suasana kembali aman dan damai. Namun, beberapa tahun kemudian, yakni 28 Maret 2016, kembali terjadi konflik. Kali ini dipicu oleh bentrokan antara kelompok pemuda di desa di Kecamatan Tobelo. Pertikaian antarpemuda ini berbuntut pada pembakaran sebuah pondok pesantren terjadi beberapa saat setelah bentrokan antara kelompok pemuda dua desa di Kecamatan Tobelo. ${ }^{5}$

Peristiwa Tobelo, makin menambah daftar konflik bernuansa agama di kawasan tersebut, yang terjadi di Ambon, Maluku, sejak Januari 1999. Peristiwa Ambon yang melibatkan dua warga yang berbeda agama (Kristen dan Islam) ini berlangsung cukup lama dan menimbulkan banyak korban nyawa dan kerusakan besar. Sejumlah rumah ibadah dari kedua belah pihak dirusak atau dibakar kelompok lawan. Pemicunya sebenarnya sepele, yakni keributan antara dua pemuda yang kebetulan berbeda agama. Jan Sihar Aritonang menulis:

\footnotetext{
4 Lihat A. Tomy Trinugroho, "Pascakonflik dan Api dalam Sekam", kompas.com, 1/10/2010, diakses pada 28 Maret 2018, pukul 14.44.

5 "Bentrok Antarpemuda, Pesantren Al Khairaat Halmahera Utara Jadi Korban", kabar24, 30 Maret 2016, diakses pada Senin, 26 Maret 2018, pukul 15.21.
} 
Konflik fisik di Ambon secara kasat mata dipicu oleh percekcokan di terminal Batumerah antara Usman, pemuda Bugis yang tinggal di kawasan Islam, Batumerah Bawah, dan Yopie Saiya, pemuda Ambon dari kawasan Kristen, Mardika, tanggal 19 Januari 1999, bertepatan dengan hari raya Idulfitri. ${ }^{6}$

\section{Toleransi}

Toleran menurut Kamus Besar Bahasa Indonesia adalah bersifat atau bersikap menenggang (menghargai, membiarkan, membolehkan) pendirian (pendapat, pandangan, kepercayaan, kebiasaan, kelakuan, dsb) yang berbeda atau bertentangan dengan pendirian sendiri. Hal ini dipertegas lagi oleh Eberhard Puntsch dengan kalimat: Toleransi adalah menghormati kebebasan sesama. Toleransi berarti mengakui hak menentukan sendiri dan hak turut menentukan yang dimiliki oleh orangorang lain. ${ }^{7}$

Kamus Oxford menegaskan bahwa toleransi adalah kemampuan untuk menenggang rasa atau keyakinan dan tindakan orang lain dan membiarkan mereka melakukannya. Kamus tersebut juga menggambarkan toleransi sebagai: kemampuan untuk menanggung penderitaan atau rasa "sakit". Deklarasi Prinsip-prinsip Toleransi UNESCO menyatakan bahwa toleransi adalah rasa hormat, penerimaan, dan penghargaan atas keragaman budaya dunia yang kaya, berbagai bentuk ekspresi diri, dan cara-cara menjadi manusia. Toleransi adalah kerukunan dalam perbedaan. J.P. Chaplin mengatakan, toleransi adalah satu sikap liberalis, atau tidak mau campur tangan dan tidak mengganggu tingkah laku dan keyakinan orang lain. ${ }^{8}$

\footnotetext{
6 Jan S. Aritonang, Sejarah Perjumpaan Kristen dan Islam di Indonesia (Jakarta: BPK Gunung Mulia, 2016), 546.

7 Eberhard Puntsch, Politik dan Martabat Manusia (Jakarta: Pustaka Sinar Harapan), 16.

8 J.P. Chaplin, Kamus Lengkap Psikologi (Jakarta: Rajagrafindo Persada, 2006), 512. Paul Edwards, ed., "Toleration" in The Encyclopedia of Philosophy, Volume 7 dan 8 (New York \& London: Macmillan Publisher, 1967), 143.
} 
Benyamin Intan dalam bukunya, Public Religion and The Pancasilabased State of Indonesia, 9 mengutip David Little membagi pengertian toleransi dalam dua bagian: Pertama, dalam definisinya yang minimal, yaitu jawaban pada seperangkat kepercayaan, praktik atau atribut, yang pada awalnya dianggap menyimpang atau tidak bisa diterima, dengan ketidaksetujuan, tetapi tanpa menggunakan kekuatan atau paksaan". Kedua, dalam bentuknya yang paling kuat, toleransi bisa didefinisikan sebagai, (sebuah) jawaban kepada seperangkat kepercayaan, praktik atau atribut, yang awalnya dianggap sebagai menyimpang atau tidak bisa diterima, dengan ketidaksetujuan yang disublimasi, tetapi tanpa menggunakan kekuatan atau paksaan". Menurut Little, "ketidaksetujuan yang disublimasi adalah ada sesuatu yang bisa dinilai, sesuatu yang membangun, baik di dalam bagian kepercayaan-kepercayaan yang menyimpang itu sendiri atau di dalam proses memberi - menerima yang terjadi di antara para pendukung ide-ide yang sedang bertikai, betapa pun besarnya ketidaksepakatan yang ada". Dalam definisi Little yang pertama ada hidup bersama, namun tak ada kebersamaan, sedang dalam definisi yang kedua, hidup bersama itu diwarnai kebersamaan, suatu kehidupan yang saling memberi dan menerima. Kehidupan bersama yang harmonis tentu saja mensyaratkan penerimaan definisi yang kedua. Toleran itu bukan hanya membutuhkan kesadaran, tetapi juga semangat, gairah, perjuangan dalam bersikap toleran demi hidup bersama yang lebih baik.

Toleransi merupakan sikap dan tindakan yang saling memberikan peluang atau kesempatan kepada pihak lain untuk melakukan sesuatu, sehingga benih-benih pertentangan antar-individu atau antarkelompok dapat dicegah. ${ }^{10}$

\footnotetext{
9 Benyamin Fleming Intan, "Public Religion" and the Pancasila-Based State of Indonesia (New York: Peter Lang Publishing, Inc., 2006), 232.

10 Elly M. Setiadi dan Usman Kolip, Pengantar Sosiologi (Jakarta: Kencana Prenada Media Group, 2011), 83.
} 
Maka dengan demikian dapat disimpulkan bahwa toleransi antarumat beragama sangat diperlukan dalam menjaga keharmonisan dalam kehidupan bermasyarakat yang terdiri dari latar belakang agama yang berbeda. Tanpa toleransi tidak mungkin ada kehidupan bersama. ${ }^{11}$

\section{Indikator Sikap Toleransi Individu}

Sikap dan perilaku toleran terhadap pemeluk agama lain merupakan faktor penting untuk terciptanya kerukunan antar agama, kerukunan intern umat beragama, kerukunan pemerintah dengan antar umat beragama. Sikap toleran yang akan diukur dalam penelitian ini adalah dalam level individu. Indikator yang menjadi alat ukur antara lain:

1. Seberapa bisa seseorang itu menerima adanya perbedaan agama di masyarakat?

2. Seberapa bisa seseorang menerima adanya perbedaan paham/keyakinan dalam satu agama dalam masyarakat kita?

3. Apakah seseorang itu bersedia bertetangga dengan pemeluk agama lain?

4. Apakah seseorang itu menerima jika tetangga yang agamanya berbeda dengan dirinya mengadakan acara keagamaan di rumahnya dengan mengundang teman-teman seagamanya?

5. Apakah seseorang itu menerima kalau rumah ibadah agama lain dibangun di sekitar tempat tinggalnya?

6. Apakah seseorang itu menerima kalau atasan di tempat kerja agamanya berbeda dengan agama yang dia anut?

7. Apakah seseorang itu menerima kalau pemeluk agama lain menjadi guru di sekolah negeri?

8. Apakah seseorang itu menerima kalau kepala desa/lurah agamanya

${ }^{11}$ Ika Fatmawati Faridah, “Toleransi Antarumat Beragama Masyarakat Perumahan” dalam Jurnal Komunitas Vol. 5, No. 1 (2013). 
berbeda dengan agamanya?

9. Apakah seseorang itu menerima jika walikota/bupati di sini agamanya beda dari agamanya?

10. Apakah seseorang itu menerima jika gubernur di provinsi ini agamanya beda dari agamanya?

11. Apakah seseorang itu menerima jika presiden kita agamanya berbeda dari agamanya?

12. Apakah seseorang itu menerima kalau anggota DPR yang mewakili daerahnya ini berbeda agama dengannya?

13. Apakah seseorang itu merasa bahwa warga yang beragama lain bersikap toleran terhadap kehadirannya tinggal di sini? ${ }^{12}$

\section{Temuan Penelitian}

Hasil penelitian yang didapat melalui angket berskala Likert dengan jumlah responden 167 orang siswa dari tiga sekolah menengah tingkat atas di Tobelo. Dengan skala tingkat toleransi: Sangat Tinggi (5); Tinggi (4); Agak Tinggi (3); Kurang Tinggi (2); Rendah (1). Survei ini menentukan bahwa tingkat toleransi dinyatakan tinggi (T) jika skor yang dihasilkan berada di atas 75\%, sedangkan skor di bawah 75\% dinyatakan rendah $(\mathrm{R})$ :

Temuan yang diperoleh dalam penelitian tersebut, dijabarkan sebagai berikut:

\begin{tabular}{|c|c|c|c|c|c|c|c|c|}
\hline No. & Nama Sekolah & $\mathbf{( 5 )}$ & $\mathbf{( 4 )}$ & $\mathbf{( 3 )}$ & $\mathbf{( 2 )}$ & $\mathbf{( 1 )}$ & Persentase & Kategori \\
\hline 1. & SMAN Halut & 35 & 13 & 3 & 1 & 1 & $239 / 265=90,18$ & $\mathrm{~T}$ \\
\hline 2. & $\begin{array}{c}\text { SMK Gotong-royong } \\
\text { Tobelo }\end{array}$ & 42 & 13 & 0 & 0 & 1 & $263 / 280=93,92$ & $\mathrm{~T}$ \\
\hline 3. & SMAK Tobelo & 39 & 16 & 2 & 0 & 1 & $266 / 290=91,72$ & $\mathrm{~T}$ \\
\hline
\end{tabular}

12 Badan Litbang dan Diklat Departemen Agama, Indikator Pembangunan Agama (Jakarta: Departemen Agama RI, 2007), 33-4. 


\begin{tabular}{|l|l|l|l|l|l|l|l|} 
Jumlah & 116 & 42 & 5 & 1 & 3 & $761 / 835=91,13$ & $\mathbf{T}$ \\
\hline
\end{tabular}

Pertanyaan nomor 1: Seberapa bisa Saudara menerima adanya perbedaan agama di masyarakat?

Sikap menerima adanya perbedaan agama di masyarakat, SMAN Halut mencatat skor 239, dengan total skor 265. Maka presentasenya adalah 90,18\%, dan masuk kategori tinggi (T). Sementara SMK Gotongroyong Tobelo dengan skor 263 dan total skor 280, presentasenya 93,92 persen, dan masuk kategori tinggi (T). SMK Tobelo dengan skor 266 dan total skor 290 adalah 91,72\%, dan tergolong tinggi (T). Secara keseluruhan, hasil dari ketiga SMA tersebut mencatat skor 761, dengan total skor 835 , maka hasilnya 91,13\% dan masuk kategori tinggi (T). Dengan demikian jelaslah bahwa tingkat toleransi penerimaan perbedaan agama di masyarakat masuk kategori tinggi ( $\mathrm{T}$ ). Artinya siswa SMA di Tobelo sangat tinggi toleransinya dengan adanya perbedaan agama di masyarakat.

Pertanyaan nomor 2: Seberapa bisa Saudara menerima adanya perbedaan paham/keyakinan dalam satu agama dalam masyarakat kita?

\begin{tabular}{|c|c|c|c|c|c|c|c|c|}
\hline No. & Nama Sekolah & $\mathbf{( 5 )}$ & $\mathbf{( 4 )}$ & $\mathbf{( 3 )}$ & $\mathbf{( 2 )}$ & $\mathbf{( 1 )}$ & Persentase & Kategori \\
\hline 1 & SMAN Halut & 24 & 22 & 6 & 1 & 0 & $218 / 265=82,26$ & $\mathrm{~T}$ \\
\hline 2 & $\begin{array}{c}\text { SMK Gotong-royong } \\
\text { Tobelo }\end{array}$ & 21 & 20 & 10 & 2 & 3 & $222 / 280=79,28$ & $\mathrm{~T}$ \\
\hline 3 & SMAK Tobelo & 24 & 26 & 4 & 1 & 3 & $241 / 290=83,10$ & $\mathrm{~T}$ \\
\hline Jumlah & & $\mathbf{6 9}$ & $\mathbf{6 8}$ & $\mathbf{2 0}$ & $\mathbf{4}$ & $\mathbf{6}$ & $\mathbf{6 9 1 / 8 3 5 = 8 2 , 7 5}$ & $\mathrm{T}$ \\
\hline
\end{tabular}

Soal toleransi dalam menerima adanya perbedaan paham/keyakinan dalam satu agama di masyarakat kita, SMAN Halut menunjukkan skor 218 , dengan total skor 265, maka persentasenya $82,26 \%$, dan masuk kategori tinggi. SMK Gotong-royong Tobelo skor 222 dan total skor 280, maka persentasenya $79,28 \%$ dan masih kategori tinggi. SMAK Tobelo 
mencatat skor 241 dengan total skor 290 dengan persentase 83,10\% dan masuk kategori T. Secara keseluruhan skor ketiganya 691, dengan total skor 835 yang hasilnya $82,75 \%$ dan berkategori tinggi (T). Artinya, adanya perbedaan paham/keyakinan dalam satu agama, bisa diterima dengan sikap toleransi tinggi.

Pertanyaan nomor 3: Apakah Saudara bersedia bertetangga dengan pemeluk agama lain?

\begin{tabular}{|c|c|c|c|c|c|c|c|c|}
\hline No. & Nama Sekolah & $\mathbf{( 5 )}$ & $\mathbf{( 4 )}$ & $\mathbf{( 3 )}$ & $\mathbf{( 2 )}$ & $\mathbf{( 1 )}$ & Persentase & Kategori \\
\hline 1. & SMAN Halut & 37 & 10 & 2 & 1 & 3 & $236 / 265=89,05$ & $\mathrm{~T}$ \\
\hline 2. & $\begin{array}{c}\text { SMK Gotong-royong } \\
\text { Tobelo }\end{array}$ & 33 & 14 & 5 & 3 & 1 & $243 / 280=86,78$ & $\mathrm{~T}$ \\
\hline 3. & SMAK Tobelo & 39 & 15 & 1 & 2 & 1 & $263 / 290=90,68$ & $\mathrm{~T}$ \\
\hline Jumlah & & $\mathbf{1 0 9}$ & $\mathbf{3 9}$ & $\mathbf{8}$ & $\mathbf{6}$ & $\mathbf{5}$ & $\mathbf{7 4 4 / 8 3 5 = 8 9 , 1 0}$ & $\mathbf{T}$ \\
\hline
\end{tabular}

Atas pertanyaan: "bersedia bertetangga dengan pemeluk agama lain", siswa SMAN Halut menunjukkan skor 236, dan total skor 265. Hasilnya: 236/265 = 89,05\% dan tergolong tinggi. Sedangkan SMK Gotong-royong catat skor 243 dari 280 total skor $=86,78 \%$ dan masih kategori tinggi. Kemudian SMK Tobelo dengan skor 263 dari 290 total skor didapat angka 90,68\%, kategori tinggi. Jika dirata-ratakan, ketiga sekolah tersebut menghasilkan skor 744: 835 total skor sama dengan 89,10\% yang masih tergolong tinggi. Artinya, sikap toleransi dalam bertetangga dengan orang yang berbeda agama, termasuk tinggi.

Pertanyaan nomor 4: Apakah Saudara menerima jika tetangga yang agamanya berbeda dengan Saudara/i mengadakan acara keagamaan di rumahnya dengan mengundang teman-teman seagamanya? 


\begin{tabular}{|c|c|c|c|c|c|c|c|c|}
\hline No. & Nama Sekolah & $\mathbf{( 5 )}$ & $\mathbf{( 4 )}$ & $\mathbf{( 3 )}$ & $\mathbf{( 2 )}$ & $\mathbf{( 1 )}$ & Persentase & Kategori \\
\hline 1. & SMAN Halut & 31 & 15 & 2 & 4 & 1 & $230 / 265=86,79$ & $\mathrm{~T}$ \\
\hline 2. & $\begin{array}{c}\text { SMK Gotong-royong } \\
\text { Tobelo }\end{array}$ & 36 & 14 & 2 & 2 & 2 & $248 / 290=88,57$ & $\mathrm{~T}$ \\
\hline 3. & SMAK Tobelo & 27 & 22 & 4 & 1 & 4 & $241 / 290=83,10$ & $\mathrm{~T}$ \\
\hline Jumlah & & $\mathbf{9 4}$ & $\mathbf{5 1}$ & $\mathbf{8}$ & $\mathbf{7}$ & $\mathbf{7}$ & $\mathbf{7 1 9 / 8 3 5 = 8 6 , 1 0}$ & $\mathbf{T}$ \\
\hline
\end{tabular}

Siswa SMAN Halut memperlihatkan skor 230, dengan total skor 265, sehingga didapat 86,79\%, dan masuk kategori tinggi. SMK Gotongroyong dengan skor 248 berbanding total skor 290, maka hasilnya $88,57 \%$, dan tergolong tinggi. Adapun SMAK Tobelo skornya 241, total skor 290. Maka diperoleh angka 83,10\%, dan masih tinggi. Bila ketiganya dijumlahkan maka didapat skor 719 dan total skor 835. Hasil keseluruhan adalah $86,10 \%$ dan masuk kategori tinggi. Artinya, toleransi dalam menerima keberadaan tetangga yang berbeda agama, masih tinggi.

Pertanyaan nomor 5: Apakah Saudara menerima kalau rumah ibadah agama lain dibangun di sekitar tempat tinggal Saudara?

\begin{tabular}{|c|c|c|c|c|c|c|c|c|}
\hline No. & Nama Sekolah & $\mathbf{( 5 )}$ & $\mathbf{( 4 )}$ & $\mathbf{( 3 )}$ & $\mathbf{( 2 )}$ & $\mathbf{( 1 )}$ & Persentase & Kategori \\
\hline 1. & SMAN Halut & 21 & 9 & 10 & 11 & 2 & $187 / 265=70.56$ & $\mathrm{R}$ \\
\hline 2. & $\begin{array}{c}\text { SMK Gotong-royong } \\
\text { Tobelo }\end{array}$ & 16 & 9 & 18 & 9 & 4 & $176 / 280=62,85$ & $\mathrm{R}$ \\
\hline 3. & SMAK Tobelo & 13 & 21 & 14 & 5 & 5 & $206 / 290=71,03$ & $\mathrm{R}$ \\
\hline Jumlah & & $\mathbf{5 0}$ & $\mathbf{3 9}$ & $\mathbf{4 2}$ & $\mathbf{2 5}$ & $\mathbf{1 1}$ & $\mathbf{5 9 5 / 8 3 5 = 7 1 , 2 5}$ & $\mathbf{R}$ \\
\hline
\end{tabular}

Bagaimana sikap kita bila rumah ibadah agama lain dibangun di sekitar tempat tinggal? Siswa SMAN Halut memperlihatkan skor 187 berbanding 265 total skor. Hasilnya 70,56\%, dan tergolong rendah (R). Hasil yang tidak jauh beda ditunjukkan oleh SMK Gotong-royong dengan skor 176 dan total skor 280, yang mendapatkan angka 62,85\%, 
dan masuk kategori rendah (R). Begitu pula dengan SMAK Tobelo, yang mencatat skor 206/290 $=71,03 \%$ (kategori R). Ketika ketiganya dirataratakan, hasilnya adalah $595 / 835=71,25 \%$, dan termasuk rendah (R). Artinya, sikap toleransi dalam menerima kehadiran rumah ibadah agama lain, tergolong rendah!

Pertanyaan nomor 6: Apakah Saudara menerima kalau atasan di tempat kerja agamanya berbeda dengan agama yang Saudara anut?

\begin{tabular}{|c|c|c|c|c|c|c|c|c|}
\hline No. & Nama Sekolah & $\mathbf{( 5 )}$ & $\mathbf{( 4 )}$ & $\mathbf{( 3 )}$ & $\mathbf{( 2 )}$ & $\mathbf{( 1 )}$ & Persentase & Kategori \\
\hline 1. & SMAN Halut & 27 & 13 & 4 & 4 & 5 & $202 / 265=76,22$ & $\mathrm{~T}$ \\
\hline 2. & $\begin{array}{c}\text { SMK Gotong-royong } \\
\text { Tobelo }\end{array}$ & 29 & 15 & 7 & 2 & 3 & $235 / 280=83,92$ & $\mathrm{~T}$ \\
\hline 3. & SMAK Tobelo & 35 & 13 & 3 & 0 & 7 & $233 / 290=80,34$ & $\mathrm{~T}$ \\
\hline Jumlah & & $\mathbf{9 1}$ & $\mathbf{4 1}$ & $\mathbf{1 4}$ & $\mathbf{6}$ & $\mathbf{1 5}$ & $\mathbf{6 8 8 / 8 3 5 = 8 2 , 3 9}$ & $\mathrm{T}$ \\
\hline
\end{tabular}

Bagaimana sikap kita jika bos atau atasan di kantor berbeda agama dengan kita? SMAN Halut menunjukkan skor 202: total skor 265, sehingga dapat $76,22 \%$, di mana toleransinya masih termasuk tinggi (T). Sedangkan siswa SMK Gotong-royong Tobelo menghasilkan skor 235, dari total skor 280. Maka diperoleh angka 83,92\%, dan tergolong kategori T. SMK Tobelo skornya 233, dengan total skor 290, jadi didapat angka $80,34 \%$, dan kategori T. Dan secara keseluruhan tingkat toleransinya mendapat skor 688/total skor $835=82,39$ persen, kategori $\mathrm{T}$ atau tinggi.

Pertanyaan nomor 7: Apakah Saudara menerima kalau pemeluk agama lain menjadi guru di sekolah negeri?

\begin{tabular}{|c|c|c|c|c|c|c|c|c|}
\hline No. & Nama Sekolah & $\mathbf{( 5 )}$ & $\mathbf{( 4 )}$ & $\mathbf{( 3 )}$ & $\mathbf{( 2 )}$ & $\mathbf{( 1 )}$ & Persentase & Kategori \\
\hline 1. & SMAN Halut & 38 & 9 & 3 & 1 & 2 & $239 / 265=90,18$ & $\mathrm{~T}$ \\
\hline 2. & $\begin{array}{c}\text { SMK Gotong-royong } \\
\text { Tobelo }\end{array}$ & 30 & 13 & 6 & 3 & 4 & $230 / 280=82,14$ & $\mathrm{~T}$ \\
\hline
\end{tabular}




\begin{tabular}{|c|c|c|c|c|c|c|c|c|} 
3. & SMAK Tobelo & 33 & 18 & 3 & 0 & 4 & $250 / 290=86,20$ & $\mathrm{~T}$ \\
\hline Jumlah & & $\mathbf{1 0 1}$ & $\mathbf{4 0}$ & $\mathbf{1 2}$ & $\mathbf{4}$ & $\mathbf{1 0}$ & $\mathbf{7 0 9 / 8 3 5}=\mathbf{8 4 , 9 1}$ & $\mathbf{T}$ \\
\hline
\end{tabular}

Apakah saudara menerima jika pemeluk agama lain menjadi guru di sekolah negeri? SMAN Halut menunjukkan skor 239 berbanding 265 total skor. Hasilnya 90,18\%, dengan toleransi tinggi (T). SMK Gotongroyong menjawab dengan skor 230 dan total skor 280. Hasilnya 230/280 = $82,14 \%$, dan kategori tinggi (T). SMAK Tobelo dengan skor 250 dan total skor $290=86,20 \%$, kategori tinggi (T). Keseluruhan mendapat skor $709 /$ total skor $835=84,91 \%$ atau termasuk kategori tinggi $(\mathrm{T})$. Jadi tingkat toleransi dalam menerima pemeluk agama lain menjadi guru di sekolah negeri, masih tinggi.

Pertanyaan nomor 8: Apakah Saudara menerima kalau kepala desa/lurah agamanya berbeda dengan agama Saudara?

\begin{tabular}{|c|c|c|c|c|c|c|c|c|}
\hline No. & Nama Sekolah & $\mathbf{( 5 )}$ & $\mathbf{( 4 )}$ & $\mathbf{( 3 )}$ & $\mathbf{( 2 )}$ & $\mathbf{( 1 )}$ & Persentase & Kategori \\
\hline 1. & SMAN Halut & 30 & 13 & 2 & 6 & 2 & $222 / 265=83,77$ & $\mathrm{~T}$ \\
\hline 2. & $\begin{array}{c}\text { SMK Gotong-royong } \\
\text { Tobelo }\end{array}$ & 22 & 13 & 14 & 4 & 3 & $215 / 280=76,78$ & $\mathrm{~T}$ \\
\hline 3. & SMAK Tobelo & 30 & 17 & 9 & 1 & 1 & $\mathbf{2 4 2 / 2 9 0 = 8 3 , 4 4}$ & $\mathrm{T}$ \\
\hline Jumlah & & $\mathbf{8 2}$ & $\mathbf{4 3}$ & $\mathbf{2 5}$ & $\mathbf{1 1}$ & $\mathbf{6}$ & $\mathbf{6 8 5 / 8 3 5 = 8 2 , 0 3}$ & $\mathbf{T}$ \\
\hline
\end{tabular}

Berdasarkan hasil penelitian di atas, siswa SMAN Halut mencatat skor 222, dan 265 total skor. Hasilnya 83,77\%, dan masuk kategori tinggi. SMK Gotong-royong mencatat skor 215 dengan total skor 280. Hasilnya $76,78 \%$, dan kategori tinggi. Sementara SMAK Tobelo dapat skor 242 dari 290 total skor, hasilnya 83\% (tinggi). Jika digabung, skornya 685, dengan total skor 835 yang menghasilkan angka 82,03\%, masih tinggi. Jadi, tingkat toleransi siswa di Tobelo masih tinggi dalam menerima kepala desa/lurah yan berbeda agama. 
Pertanyaan nomor 9: Apakah Saudara menerima jika walikota/bupati di sini agamanya beda dari agama Saudara?

\begin{tabular}{|c|c|c|c|c|c|c|c|c|}
\hline No. & Nama Sekolah & $\mathbf{( 5 )}$ & $\mathbf{( 4 )}$ & $\mathbf{( 3 )}$ & $\mathbf{( 2 )}$ & $\mathbf{( 1 )}$ & Persentase & Kategori \\
\hline 1. & SMAN Halut & 28 & 14 & 1 & 10 & 0 & $219 / 265=82,64$ & $\mathrm{~T}$ \\
\hline 2. & $\begin{array}{c}\text { SMK Gotong-royong } \\
\text { Tobelo }\end{array}$ & 32 & 16 & 4 & 4 & 0 & $244 / 280=87,14$ & $\mathrm{~T}$ \\
\hline 3. & SMAK Tobelo & 28 & 19 & 7 & 1 & 3 & $242 / 290=83,44$ & $\mathrm{~T}$ \\
\hline Jumlah & & $\mathbf{8 8}$ & $\mathbf{4 9}$ & $\mathbf{1 2}$ & $\mathbf{1 5}$ & $\mathbf{3}$ & $\mathbf{6 9 7 / 8 3 5 = 8 3 , 4 7}$ & $\mathrm{T}$ \\
\hline
\end{tabular}

Bagaimana penerimaan saudara jika bupati/walikota berbeda agama dengan saudara? SMAN Halut punya skor 219 dan total skor 265. Hasilnya 82,64\% (T). SMK Gotong-royong dengan skor 244, dan total skor 280. Hasilnya 87,14\% (T). SMAK Tobelo dengan skor 242/290 total skor $=83,44 \%$. Ketika ketiganya dirata-ratakan, maka didapat skor $697 / 835=83,47 \%$ (kategori tinggi). Artinya sikap toleransi dalam menerima bupati/walikota yang berbeda agama, masih tinggi di kalangan pelajar SMA Tobelo.

Pertanyaan nomor 10: Apakah Saudara menerima jika gubernur di provinsi ini agamanya beda dari agama Saudara?

\begin{tabular}{|c|c|c|c|c|c|c|c|c|}
\hline No. & Nama Sekolah & $\mathbf{( 5 )}$ & $\mathbf{( 4 )}$ & $\mathbf{( 3 )}$ & $\mathbf{( 2 )}$ & $\mathbf{( 1 )}$ & Persentase & Kategori \\
\hline 1. & SMAN Halut & 34 & 13 & 0 & 6 & 0 & $234 / 265=88,30$ & $\mathrm{~T}$ \\
\hline 2. & $\begin{array}{c}\text { SMK Gotong-royong } \\
\text { Tobelo }\end{array}$ & $\mathbf{2}$ & 20 & 2 & 5 & 0 & $241 / 280=86,07$ & $\mathrm{~T}$ \\
\hline 3. & SMAK Tobelo & 31 & 19 & 5 & 0 & 3 & $249 / 290=85.86$ & $\mathrm{~T}$ \\
\hline Jumlah & & $\mathbf{9 4}$ & $\mathbf{5 2}$ & $\mathbf{7}$ & $\mathbf{1 1}$ & $\mathbf{3}$ & $\mathbf{7 2 4 / 8 3 5 = 8 6 , 7 0}$ & $\mathbf{T}$ \\
\hline
\end{tabular}

Bagaimana sikap penerimaan saudara jika gubernur di provinsi ini agamanya beda dari agama Saudara? SMAN Halut mencatat skor 234, dan total skor 265. Hasilnya $=88,30 \%$ (tinggi). SMK Gotong-royong dapat skor 241, dan total skor 280, maka hasilnya 86,07\% (tinggi). Dan SMAK 
Tobelo menunjukkan skor 249 dan total skor 290, dan hasilnya 85,86\% (tinggi). Seluruhnya digabung menjadikan skor 724, dan total skor 835, dan hasilnya 86,70\% (tinggi). Artinya, siswa SMA di Tobelo menerima dengan sikap toleransi yang tinggi bila gubernur di daerah mereka berbeda agama dengan mereka.

Pertanyaan nomor 11: Apakah Saudara menerima jika presiden kita agamanya berbeda dari agama Saudara/i?

\begin{tabular}{|c|c|c|c|c|c|c|c|c|}
\hline No. & Nama Sekolah & $\mathbf{( 5 )}$ & $\mathbf{( 4 )}$ & $\mathbf{( 3 )}$ & $\mathbf{( 2 )}$ & $\mathbf{( 1 )}$ & Persentase & Kategori \\
\hline 1. & SMAN Halut & 42 & 5 & 2 & 4 & 0 & $244 / 265=92,07$ & $\mathrm{~T}$ \\
\hline 2. & $\begin{array}{c}\text { SMK Gotong-royong } \\
\text { Tobelo }\end{array}$ & 36 & 14 & 1 & 4 & 1 & $248 / 280=88,57$ & $\mathrm{~T}$ \\
\hline 3. & SMAK Tobelo & 39 & 15 & 1 & 0 & 3 & $261 / 290=90,00$ & $\mathrm{~T}$ \\
\hline Jumlah & & $\mathbf{1 1 7}$ & $\mathbf{3 4}$ & $\mathbf{4}$ & $\mathbf{8}$ & $\mathbf{4}$ & $\mathbf{7 5 3 / 8 3 5 = 9 0 , 1 7}$ & $\mathrm{T}$ \\
\hline
\end{tabular}

Jika presiden berbeda agama dengan saudara? SMAN Halut mencatat skor 244, dan total skor 265, hasilnya adalah 92,07\% (tinggi). SMK Gotong-royong dengan skor 248, dan total skor 280, maka hasilnya 88,57\% (tinggi). SMAK Tobelo skornya 261, dan total skor 290, sehingga hasilnya 90,00\% (tinggi). Secara keseluruhan adalah skor 753, dan total skor 835, maka hasilnya 90,17 atau kategori tinggi (T). Jadi, bagi mayoritas siswa Tobelo menerima jika presiden negeri ini berbeda agama dari mereka.

Pertanyaan nomor 12: Apakah Saudara menerima kalau anggota DPR yang mewakili daerah Saudara ini agamanya beda dari agama Saudara?

\begin{tabular}{|c|c|c|c|c|c|c|c|c|}
\hline No. & Nama Sekolah & $\mathbf{( 5 )}$ & $\mathbf{( 4 )}$ & $\mathbf{( 3 )}$ & $\mathbf{( 2 )}$ & $\mathbf{( 1 )}$ & Persentase & Kategori \\
\hline 1. & SMAN Halut & 32 & 14 & 4 & 3 & 0 & $234 / 265=88,30$ & $\mathrm{~T}$ \\
\hline 2. & $\begin{array}{c}\text { SMK Gotong-royong } \\
\text { Tobelo }\end{array}$ & 23 & 18 & 3 & 4 & 8 & $212 / 280=75,71$ & $\mathrm{~T}$ \\
\hline
\end{tabular}




\begin{tabular}{|c|c|c|c|c|c|c|c|c|} 
3. & SMAK Tobelo & 29 & 22 & 3 & 1 & 3 & $247 / 290=85,17$ & $\mathrm{~T}$ \\
\hline Jumlah & & $\mathbf{8 4}$ & $\mathbf{5 4}$ & $\mathbf{1 0}$ & $\mathbf{8}$ & $\mathbf{1 1}$ & $\mathbf{6 9 3} / \mathbf{8 3 5}=\mathbf{8 2 , 9 9}$ & $\mathbf{T}$ \\
\hline
\end{tabular}

Apakah saudara menerima kalau anggota DPR yang mewakili daerah saudara berbeda agama dari saudara? SMAN Halut catat skor 234, dari total skor 265, sehingga hasilnya 88,30\% (tinggi). SMK Gotong-royong mencatat skor 212 dari 280 total skor, dan mendapat angka 75,71\%, masuk kategori tinggi. SMAK Tobelo skornya 247, dan total skor 290, maka hasilnya 85,17\% (tinggi). Secara keseluruhan, skor 693/total skor $835=82,99 \%$. Ini menunjukkan tingkat toleransi di kalangan siswa SMA Tobelo terhadap wakil rakyat yang berbeda agama dengan mereka, masuk kategori tinggi.

Pertanyaan nomor 13: Apakah Saudara merasa warga yang beragama lain bersikap toleran terhadap kehadiran Saudara tinggal di sini?

\begin{tabular}{|c|c|c|c|c|c|c|c|c|}
\hline No. & Nama Sekolah & $\mathbf{( 5 )}$ & $\mathbf{( 4 )}$ & $\mathbf{( 3 )}$ & $\mathbf{( 2 )}$ & $\mathbf{( 1 )}$ & Persentase & Kategori \\
\hline 1. & SMAN Halut & 20 & 13 & 6 & 5 & 9 & $189 / 265=71,32$ & $\mathrm{R}$ \\
\hline 2. & $\begin{array}{c}\text { SMK Gotong-royong } \\
\text { Tobelo }\end{array}$ & 10 & 19 & 11 & 12 & 4 & $179 / 280=63,92$ & $\mathrm{R}$ \\
\hline 3. & SMAK Tobelo & 22 & 12 & 6 & 2 & 16 & $196 / 290=67,58$ & $\mathrm{R}$ \\
\hline Jumlah & & $\mathbf{5 2}$ & $\mathbf{4 4}$ & $\mathbf{2 3}$ & $\mathbf{1 9}$ & $\mathbf{2 9}$ & $\mathbf{5 4 2 / 8 3 5 = 6 4 , 9 1}$ & $\mathbf{R}$ \\
\hline
\end{tabular}

Apakah Saudara merasa warga yang beragama lain bersikap toleran terhadap kehadiran Saudara tinggal di sini? Atas pertanyaan ini, SMAN Halut menunjukkan skor 189, dari total skor 265, dan hasilnya $71,32 \%$ (kategori rendah atau R). SMK Gotong-royong mencatat skor 179 dari total skor 280, dan hasilnya 63,92\%, tergolong rendah (R). Dan SMAK Tobelo dengan skor 196 dari total skor 290 mendapat hasil 67,58\%, kategori rendah (R). Seluruhnya menjadi skor 542 dari total skor 835, dengan hasil 64,91\%, masuk kategori rendah (R). Jadi, dapat dikatakan, siswa SMA Tobelo menganggap sikap toleransi masyarakat yang berbeda agama di daerah mereka tergolong rendah. 


\section{Pembahasan}

Berdasarkan survei ditemukan bahwa secara umum tingkat toleransi beragama di Tobelo adalah tinggi dengan skor rata-rata $86 \%$. Dalam arti, para siswa secara umum menerima adanya perbedaan agama di masyarakat, dan tidak keberatan apabila bertetangga dengan warga yang berbeda agama, tidak menjadi masalah apabila kepala daerah, wakil rakyat, bahkan presiden adalah orang yang berbeda agama dengannya.

Namun hal yang menarik adalah untuk pertanyaan: "Apakah Saudara menerima kalau rumah ibadah agama lain dibangun di sekitar tempat tinggal Saudara?" Skor keseluruhan adalah rendah dengan skor rata-rata $71,25 \%$, berarti di bawah $75 \%$. Hal yang sama juga terjadi pada pertanyaan: "Apakah Saudara merasa warga yang beragama lain bersikap toleran terhadap kehadiran Saudara tinggal di sini?" Skor untuk butir petanyaan itu rata-rata 64,91, dan masuk dalam kategori rendah.

Berdasarkan data survei dapat dipahami bahwa tingginya penolakan terhadap eksisitensi agama tertentu terlihat juga pada kurangnya keyakinan toleransi antaragama. Kehadiran tempat ibadah dicurigai sebagai bukti intoleransi. Hal seperti ini juga terjadi di Manokwari, Papua. Kehadiran masjid yang kemegahannya melampaui gereja-gereja yang ada di Manokwari membuktikan rendahnya toleransi antaragama. Dengan demikian dapat dikaitkan bahwa penolakan terhadap kehadiran rumah ibadah lain secara berhubungan langsung dengan kecurigaan masyarakat terhadap toleransi antaragama. Dalam dunia yang makin heterogen, pembangunan rumah ibadah dari berbagai agama tidak dapat dihindari, karena semua pemeluk agama memerlukan tempat ibadah.

Di Indonesia kebebasan beragama bukan hanya kebebasan untuk memeluk agama dan beribadah sesuai agamanya masing-masing, tetapi juga beribadah secara berkelompok di dalam rumah ibadah. Dalam konflik Tobelo yang meletus lagi pada tahun 2016, salah satu sasaran amuk adalah rumah ibadah. Demikian juga pada masa-masa konflik 
sektarian di tempat lain, salah satu hal yang menjadi sasaran utama penghancuran adalah rumah ibadah pihak lain. Mengapa? Karena rumah ibadah menjadi simbol adanya eksisitensi agama tertentu. Menghancurkan rumah ibadah sama saja dengan menolak hadirnya agama tertentu di tempat komunitas yang berbeda agama.

Berdasarkan survei di atas dapat diketahui bahwa Tobelo masih memerlukan usaha integrasi. Secara khusus integrasi antaragama perlu dipupuk melalui sekolah. Kelompok-kelompok antaragama dalam sebuah sekolah, atau antarsekolah perlu dibangun untuk terjadinya integrasi antarkelompok agama. Dengan adanya komunitas siswa beragam agama diharapkan kecurigaan antarpemeluk agama yang pernah tumbuh ketika terjadi konflik agama perlahan dapat ditekan. Dan apabila kecurigaan antarkelompok siswa dan selanjutnya dalam konteks lebih luas, yakni masyarakat, sudah tidak ada lagi, maka pembangunan rumah ibadah tidak dicurigai sebagai usaha untuk menaklukkan agama lain.

\section{Kesimpulan}

Berdasarkan peristiwa yang diangkat dalam tulisan ini, dapat disimpulkan bahwa suatu kehidupan yang penuh toleransi di sebuah wilayah yang sudah berlangsung lama, bisa saja rusak dalam sekejap oleh isu-isu yang sebenarnya sepele, terlebih apabila isu itu dikaitkan dengan agama. Wilayah Tobelo di Maluku Utara telah membuktikan hal tersebut, di mana masyarakat yang sejak dahulu kala hidup rukun dan damai meski berbeda agama, tiba-tiba saling serang, gara-gara termakan isu yang belum jelas kebenarannya.

Toleransi adalah sikap hidup yang harus dimiliki oleh semua elemen masyarakat, terlebih di sebuah wilayah atau negara yang heterogen. Sikap mau menerima perbedaan, dan menghargai hak hidup orang lain yang berbeda agama, suku, ras, dan sebagainya, akan menghindarkan terjadinya konflik. 
Hasil survei terhadap siswa di sekolah menengah Tobelo, secara umum menunjukkan bahwa tingkat toleransi masih tinggi. Pada umumnya mereka menerima atau tidak menjadi masalah apabila hidup dan berinteraksi dengan masyarakat yang berbeda agama. Namun berdasarkan survei di atas, tingkat toleransi atas kehadiran rumah ibadah agama lain masih rendah.

Diperlukan pendidikan toleransi yang terus-menerus di kalangan siswa supaya mereka bisa menerima sepenuhnya perbedaan yang adalah realita dalam kehidupan masyarakat Indonesia. 